\title{
UJI DAYA HAMBAT EKSTRAK RUMPUT LAUT GRACILARIA SP TERHADAP PERTUMBUHAN BAKTERI STAPHYLOCOCCUS AUREUS
}

\author{
${ }^{1}$ Torar S. S. Toy, \\ ${ }^{2}$ Benedictus S. Lampus, \\ ${ }^{3}$ Bernat S. P. Hutagalung
}

\author{
${ }^{1}$ Kandidat Skripsi Program Studi Pendidikan Dokter Gigi Fakultas Kedokteran \\ ${ }^{2}$ Bagian IlmuKesehatan Masyarakat Fakultas Kedokteran \\ ${ }^{3}$ Program Studi Pendidikan Dokter Gigi Fakultas Kedokteran \\ Universitas Sam Ratulangi Manado \\ E-mail: Steven_troy36@yahoo.com
}

\begin{abstract}
Infection usually caused by microorganism such as bacterial. One example of infection is abscess which caused by Staphylococcus aureus. Staphylococcus aureus is a pathogenic bacterial in mouth. Seaweed is a part of sea plants. Nowadays, seaweed has been used as material of agar-agar, alginate, and even medicine. Indonesia has good potential to develop and use its richness at the sea. One of species that has been cultivated is Gracilaria verrucosa or known with local name "bulung rambu" (Bali) or "sango-sango" (Sulawesi). The characteristics of Gracilaria verrucosa is thallus silindris, slick, and has yellowish-brown or yellowish-green. Green, red, or brown seaweed is a potential source of bioactive compound that useful for pharmacy industry improvement like antibacterial, antivirus, antifungal, and cytostatic. This study purpose was to find out if seaweed extract (Gracilaria sp.) can inhibit growth of Staphylococcus aureus. This study was an experimental laboratory with true experimental design and posttest only control design. study subject are seaweed extract Gracilaria sp. that dissolved with 95\% ethanol which evaporated in oven. Inhibition zone of Gracilaria sp. extract evaporated in the oven at each repeated were $2.5 \mathrm{~mm}, 3.5 \mathrm{~mm}$, $3 \mathrm{~mm}$. Inhibition zone created from Gracilaria sp. extract that evaporated with vacuum rotary evaporator in each repeated were $2 \mathrm{~mm}, 2 \mathrm{~mm}$, and $2.5 \mathrm{~mm}$. Study results showed that seaweed extract (Gracilaria sp.) didn’t have exhibition zone against Staphylococcus aureus.
\end{abstract}

Keywords: inhibition test, seaweed (gracilaria sp), staphylococcus aureus.

Abstrak: Penyakit infeksi yang biasanya disebabkan oleh mikroorganisme yaitu bakteri.
Salah satu contoh penyakit infeksi tersebut yaitu abses yang disebabkan oleh bakteri
Staphylococcus aureus. Staphylococcus aureus adalah patogen utama dalam rongga mulut.
Rumput laut merupakan bagian dari tumbuhan laut perairan. Saat ini rumput laut telah
dimanfaatkan sebagai bahan baku industri agar-agar, dan alginat bahkan obat-obatan.
Indonesia mempunyai potensi yang baik untuk mengembangkan dan memanfaatkan kekayaan
lautnya. Salah satu jenis yang sudah banyak dibudidayakan adalah Gracilaria verrucosa atau
dikenal dengan nama daerah bulung rambu (bali) atau sango-sango (sulawesi). Ciri-ciri dari
Gracilaria verrucosa, yaitu thallus silindris, licin, dan berwarna kuning-coklat atau kuning-
hijau.Rumput laut hijau, merah ataupun coklat merupakan sumber potensial senyawa bioaktif
yang sangat bermanfaat bagi pengembangan industri farmasi seperti sebagai antibakteri,
antivirus, antijamur dan sitotastik. Penelitian ini bertujuan untuk mengetahui apakah ekstrak
rumput laut (Gracilaria sp.) dapat menghambat pertumbuhan bakteri Staphylococcus aureus.
Penelitian ini merupakan penelitian eksperimental laboratorium, menggunakan rancangan
eksperimental murni (true experimental design) dengan rancangan penelitian posttest only 
control design. Subjek dari penelitian ini ialah ekstrak rumput laut Gracilaria sp. yang dilarutkan dengan etanol 95\% yang dievaporasi menggunakan rotary vacuum evaporator dan dipanaskan dalam oven. zona hambat dari ekstrak Gracilaria sp. yang dievaporasi dengan oven pada masing-masing pengulangan ialah 2,5 mm, 3,5 mm, $3 \mathrm{~mm}$. Demikian juga zona hambat yang terbentuk dari ekstrak Gracilaria sp. yang dievaporasi dengan vacuum rotary evaporator pada masing-masing pengulangan ialah $2 \mathrm{~mm}, 2 \mathrm{~mm}$, dan 2,5 mm. Hasil penelitian menunjukkan bahwa ekstrak rumput laut (Gracilaria sp.) tidak memiliki daya hambat terhadap bakteri Staphylococcus aureus.

Kata kunci: uji daya hambat, rumput laut (gracilaria sp.), staphylococcus aureus.

Kesehatan gigi dan mulut merupakan hal yang penting bagi kesehatan secara umum seseorang, karena gigi dan mulut yang sehat memungkinkan seseorang untuk makan, berbicara dan bersosialisasi dengan nyaman tanpa mengalami rasa sakit. Pada kenyataannya kondisi ini sulit dicapai dan hal ini tergambar lewat banyaknya masalah kesehatan gigi dan mulut yang ditemukan di masyarakat seperti penyakit periodontal, karies gigi, dan penyakit infeksi lainnya.

Data Riskesdas 2013 menunjukkan bahwa prevalensi nasional masalah gigi dan mulut adalah 25,9\%, sebanyak 14 provinsi mempunyai prevalensi masalah gigi dan mulut di atas angka nasional. Provinsi Sulawesi Utara merupakan salah satu di antaranya dengan prevalensi masalah kesehatan gigi dan mulut sebesar 31,6\%. Penyakit karies gigi merupakan salah satu penyakit infeksi yang banyak diderita oleh masyarakat. Menurut data Riskesdas 2013 indeks karies yang diukur dari indeks DMF-T secara nasional menunjukkan angka 4,6, sedangkan indeks DMF-T provinsi Sulawesi Utara 5,4. Angka ini menunjukkan bahwa rata-rata penduduk memiliki kira-kira 5 gigi yang berlubang. Hasil Riskesdas 2013 juga menunjukkan bahwa prevalensi karies aktif penduduk Sulawesi Utara sebesar $57,0 \%$ dengan prevalensi pengalaman karies $80,2 \%{ }^{1}$

Karies sebagai salah satu penyakit infeksi apabila dibiarkan atau tidak ditangani dengan baik dapat menyebabkan infeksi yang lebih parah pada jaringan periapikal gigi dan jaringan mulut berupa pembengkakan atau abses. Salah satu kuman yang berperan pada infeksi rongga mulut yakni Staphylococcus aureus. Staphylococcus aureus ialah patogen utama dalam rongga mulut. Infeksi jenis bakteri ini terutama dapat menimbulkan penyakit pada manusia. Setiap jaringan tubuh dapat diinfeksi olehnya dan menyebabkan timbulnya penyakit dengan tanda-tanda yang khas, yaitu peradangan, nekrosis, dan pembentukan abses. Langkah pengobatan untuk penyakit infeksi ini ialah dengan pemberian agen anti bakteri yang dapat menghambat pertumbuhan bakteri yang menginfeksi. Antibiotik sebagai agen anti bakteri telah banyak ditemukan tetapi di antaranya menjadi tidak efektif karena banyaknya bakteri yang resisten akibat pemakaian antibiotik yang irrasional. ${ }^{2}$

Resistensi kuman terhadap antibiotik mengakibatkan infeksi sulit diobati, oleh karena itu banyak penelitian dilakukan untuk menemukan obat antibakteri lainnya. Belakangan ini perkembangan penelitian lebih lanjut mengarah pada pengembangan bahan alami. Penggunaan obat dari bahan alami dinilai lebih aman dan memiliki efek samping relatif lebih kecil. Rumput laut merupakan salah satu bahan alam yang dapat digunakan untuk mempercepat penyembuhan luka. Vitamin $\mathrm{C}$ dalam rumput laut mengandung antioksidan seperti vitamin A, juga menjaga kekuatan tulang, gigi, gusi, kesehatan kulit dan membantu penyembuhan luka, serta memperkuat pembuluh darah. Adanya kandungan kalsium yang besar dapat mencegah keropos tulang, membantu pertumbuhan tulang dan gigi, dan meningkatkan metabolisme dalam tubuh. ${ }^{3}$

Beberapa alasan yang dikemukan menjadi dasar bagi penulis untuk melakukan uji daya hambat ekstrak rumput laut (Gracilaria sp.) terhadap pertumbuhan bakteri Staphylococcus aureus. 


\section{METODE PENELITIAN Alat dan Bahan}

Penelitian ini merupakan penelitian eksperimental laboratorium, menggunakan rancangan eksperimental murni (true experimental design) dengan rancangan penelitian posttest only control design. Bahan-bahan yang digunakan dalam penelitian ini yaitu rumput laut jenis Gracilaria sp. yang diperoleh dari perairan pantai Likupang, bakteri Staphylococcus aureus, nutrient agar (NA), Agar MüllerHinton (MHA), Brain Heart Infusion Broth (BHI-B), etanol 95\%, amoksisilin, larutan $\mathrm{BaCl}_{2} 1 \%$, larutan $\mathrm{H}_{2} \mathrm{SO}_{4} 1 \%$ dan aquades.

Alat-alat yang yaitu: Tabung reaksi, jarum ose, cawan petri, pinset, kapas lidi steril, kertas saring, oven, autoclave, incubator, perforator, spidol, kamera, batang pengaduk, timbangan, api bunsen, jangka sorong, wadah steril, sarung tangan, vacuum evaporator, tabung erlenmeyer, masker.

\section{Metode Penelitian \\ Sterilisasi alat}

Alat-alat yang digunakan dalam penelitian ini disterilkan terlebih dahulu. Alat-alat gelas disterilkan dalam oven pada suhu $170^{\circ} \mathrm{C}$ selama \pm 1 jam (sterilisasi kering), media disterilkan dalam autoclave pada suhu $121^{\circ} \mathrm{C}$ selama 15 menit (sterilisasi basah).

\section{Ekstraksi rumput laut Gracilaria sp.}

Sampel rumput laut yang telah dikeringkan ditimbang seberat 25gr dan dibungkus dengan kertas saring, kemudian dimasukkan ke dalam tabung soklet lalu alirkan air pendingin melalui kondensor. Tabung ekstraksi dipasang pada alat destilasi soklet dengan pelarut etanol 95\% selama 4 jam. Sebagian ekstrak dimasukan ke dalam botol timbang yang bersih lalu diuapkan dengan rotary vacuum evaporator pada temperatur $40^{\circ} \mathrm{C}$ sampai etanol menguap. Sebagian ekstrak lainnya dimasukan ke dalam botol timbang kemudian dievaporasi dalam oven. Bagian sisa dari penguapan etanol disebut dengan ekstrak pekat. Berat ekstrak kemudian ditimbang, diperoleh berat ekstrak dengan menggunakan rotary vacuum evaporator seberat 1,8502 gr, sedangkan berat ekstrak yang dievaporasi menggunakan oven seberat 1,1969 gr.

\section{Prosedur pengambilan bakteri}

Bakteri Staphylococcus aureus yang digunakan dalam penelitian ini diambil dari stok bakteri murni yang berada di Badan Pemeriksa Obat dan Makanan (BPOM) Manado. Bakteri disimpan pada agar miring kemudian dimasukan ke dalam wadah steril yang berada dalam suasana anaerob dan ditutup sehingga sterilisasi tetap terjaga untuk dibawa ke tempat penelitian. Jika sudah mendekati waktu untuk digunakan, bakteri diinkubasi dalam inkubator pada suhu $37^{\circ} \mathrm{C}$.

\section{Pembuatan standar kekeruhan larutan McFarland}

Larutan baku McFarland terdiri atas 2 komponen, yaitu larutan $\mathrm{BaCl}_{2} 1 \%$ dan $\mathrm{H}_{2} \mathrm{SO}_{4} \quad 1 \%$. Larutan $\mathrm{BaCl}_{2} \quad 1 \%$ sebanyak $0,05 \mathrm{ml}$ dicampur dengan larutan $\mathrm{H}_{2} \mathrm{SO}_{4}$ $1 \%$ sebanyak 9,95 $\mathrm{ml}$ dan dikocok homogen. Nilai absorban larutan baku McFarland 0,5 ekuivalen dengan suspensi sel bakteri konsentrasi $1,5 \times 10^{8} \mathrm{CFU} / \mathrm{ml}$.

\section{Penanaman bakteri pada lapisan pembenihan}

Bakteri yang telah diinkubasi diambil koloninya dari media agar miring dengan menggunakan jarum ose steril. Koloni yang diambil dimasukan ke dalam media BHI-B sampai kekeruhannya sama dengan standar McFarland. Lidi kapas steril dicelupkan ke dalam bakteri hingga basah kemudian diperas dengan menekankan pada dinding tabung reaksi bagian dalam, kemudian digores merata pada media MHA.

\section{Pembuatan larutan kontrol positif}

Kontrol positif dibuat dengan sediaan bubuk obat amoksisilin. Pembuatan larutan ini mengacu pada minimal inhibitory concentration (MIC) amoksisilin terhadap S. aureus, yaitu $2,0178 \mathrm{mg} / \mathrm{ml}$ dicampur dengan pelarut aquades hingga homogen. 
Toy, Lampus, Hutagalung: Daya hambat ekstrak...

\section{Metode Pengujian}

Metode pengujian yang digunakan ialah metode modifikasi Kirby-Bauer dengan menggunakan cakram kertas saring. Kertas saring dibentuk seperti cakram dengan menggunakan perforator sebanyak 12 cakram. Cakram pertama diberi larutan ekstrak pekat rumput laut Gracilaria sp. yang sudah dilarutkan dengan etanol 95\% dan dievaporasi dengan vacuum rotary evaporator. Cakram ke dua diberi ekstrak pekat rumput laut yang sudah dilarutkan dengan etanol 95\% dan dievaporasi dengan oven. Cakram ke tiga diberi kontrol positif yaitu amoksisilin yang sudah dilarutkan dengan aquades, dan pada cakram ke empat yang merupakan kontrol negatip diberi etanol 95\%. Cakram diletakkan pada pada media MHA, perlakuan yang sama dilakukan sebanyak 3 cawan petri. Setelah itu, cawan petri diinkubasi dalam inkubator pada suhu $37^{0} \mathrm{C}$ selama 24 jam.

\section{Pengamatan dan Pengukuran}

Pengamatan dilakukan selama 24 jam masa inkubasi. Zona bening sekitar cakram merupakan petunjuk kepekaan bakteri terhadap bahan antibakteri yang digunakan sebagai bahan uji dan dinyatakan dengan luas zona hambat. Zona hambat yang terbentuk di sekitar cakram kertas saring diukur diameter vertikal dan diameter horizontal dengan satuan $\mathrm{mm}$ menggunakan jangka sorong (Gambar 1).

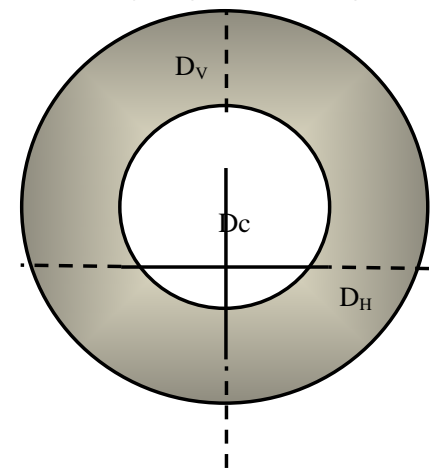

Gambar 1. Pengukuran diameter zona hambat

Keterangan :

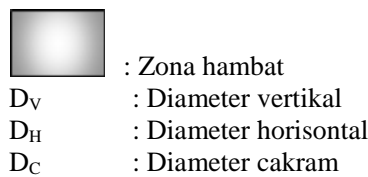

Diameter zona hambat diukur dengan rumus :

$$
\frac{\left(D_{V}-D_{C}\right)+\left(D_{H}-D_{C}\right)}{2}
$$

\section{Analisis Data}

Data hasil penelitian dihitung secara manual, kemudian data yang sudah diolah disajikan dalam bentuk tabel.

\section{HASIL DAN BAHASAN PENELITIAN}

Pengujian daya hambat dilakukan dengan mengukur diameter zona hambat yang dihasilkan pada media yang mengandung bakteri Staphylococcus Aureus setelah dilakukan inkubasi selama 24 jam pada suhu $37^{\circ} \mathrm{C}$. Media yang sudah diinkubasi diukur diameternya dengan menggunakan jangka sorong dalam satuan milimeter. Luas zona hambat dihitung dengan rumus lalu dimasukan pada tabel hasil pengamatan. Media yang sudah diinkubasi dan siap diamati dapat dilihat pada Gambar 2.

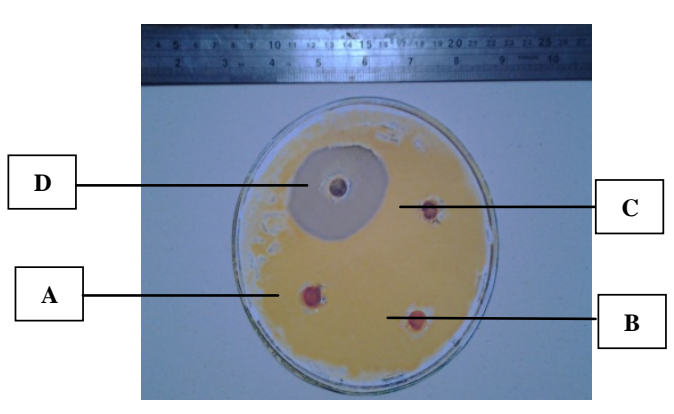

Gambar 2. Cakram pada media Agar Müller-Hinton

Keterangan :

A : Cakram yang diberi ekstrak Gracilaria sp. yang dievaporasi dengan vacuum rotary evaporator.

B : Cakram yang diberi ekstrak Gracilaria sp. yang dievaporasi dengan oven.

C : Cakram yang diberi etanol $95 \%$

D : Cakram yang diberi amoksisilin yang dilarutkan dengan aquades

Zona hambat yang dihasilkan dari masing-masing perlakuan memiliki diameter yang berbeda-beda dan bentuk yang tidak beraturan. Oleh karena itu, pengamatan dilakukan dengan mengukur diameter horizontal dan diameter vertikal dari zona yang terbentuk di sekitar cakram. Ke dua diameter tersebut dimasukan ke dalam rumus untuk mencari nilai rerata 
luas zona hambat. Hasil pengukuran luas zona hambat yang terbentuk di sekitar cakram dapat dilihat pada Tabel 1 berikut ini :

Tabel 1. Diameter zona hambat terhadap bakteri Staphylococcus Aureus

\begin{tabular}{ccccc}
\hline \multirow{2}{*}{ Pengulangan } & \multicolumn{4}{c}{ Diameter zona hambat (mm) } \\
\cline { 2 - 5 } & Ekstrak & Ekstrak & Kontrol & Kontrol \\
$\mathbf{1}$ & I & II & Positif & Negatif \\
$\mathbf{2}$ & 2 & 2,5 & 29,1 & 3,5 \\
$\mathbf{3}$ & 2 & 3,5 & 31,5 & 5,5 \\
Rerata & 2,5 & 3 & 27,5 & 4,5 \\
& 2,2 & 3 & 29,5 & 4,5 \\
\hline
\end{tabular}

Keterangan :

Ekstrak I

: Ekstrak yang dievaporasi dengan vacuum evaporator.

Ekstrak II

: Ekstrak yang dievaporasi dengan oven.

Kontrol positif : Amoksisilin yang dilarutkan dengan aquades.

Kontrol negatif : Etanol 95\%

Data hasil penelitian pada Tabel 1 memperlihatkan diameter zona hambat ekstrak rumput laut I reratanya sebesar 2,2 $\mathrm{mm}$, lebih kecil dari diameter cakram (6 $\mathrm{mm}$ ); diameter zona hambat ekstrak rumput laut II reratanya sebesar $3 \mathrm{~mm}$, lebih kecil dari diameter cakram; diameter kontrol positip (amoksisilin) menunjukkan hasil rerata sebesar 29,5 $\mathrm{mm}$ (lebih besar dari diameter cakram) dan kontrol negatip (etanol 95\%) menunjukkan hasil rerata sebesar 4,5 mm (lebih kecil dari diameter cakram).

Hasil penelitian yang menunjukkan ada tidaknya daya hambat ekstrak rumput laut disajikan pada Tabel 2. Data pada Tabel 2 menunjukkan bahwa ekstrak rumput laut Gracillaria sp. yang dievaporasi menggunakan vacuum rotary evaporator dan ekstrak rumput laut yang dievaporasi menggunakan oven keduanya tidak memiliki daya hambat.

Seiring perkembangan zaman, terdapat perkembangan jumlah bakteri yang resisten terhadap antibiotik. pada zaman sekarang semakin banyak obat-obatan yang diperoleh dari bahan alami. Indonesia merupakan negara kepulauan yang sangat luas dan memiliki kekayaan sumberdaya alam hayati laut yang besar. Rumput laut merupakan salah satu komoditas hasil laut yang potensial untuk dikembangkan dengan jumlah sekitar 6000 jenis. ${ }^{4,5}$

Tabel 2. Pengukuran ada tidaknya daya hambat ekstrak rumput laut terhadap bakteri Staphylococcus Aureus

\begin{tabular}{ccccc}
\hline Pengulangan & $\begin{array}{c}\text { Diameter } \\
\text { Zona } \\
\text { Hambat } \\
\text { Ekstrak I }\end{array}$ & $\begin{array}{c}\text { Daya } \\
\text { Hambat }\end{array}$ & $\begin{array}{c}\text { Diameter } \\
\text { Zona } \\
\text { Hambat } \\
\text { Ekstrak II }\end{array}$ & $\begin{array}{c}\text { Daya } \\
\text { Hambat }\end{array}$ \\
\hline 1 & 2 & - & 2,5 & - \\
2 & 2 & - & 3,5 & - \\
3 & 2,5 & - & 3 & - \\
Rerata & 2,2 & - & 3 & - \\
\hline
\end{tabular}

Rumput laut senyawa kimia sebagai metabolit primer yang disebut hidrokoloid. Hidrokoloid telah dimanfaatkan untuk berbagai bahan industri seperti agar-agar, karaginan, alginat, dan sebagainya. Selain metabolit primer rumput laut juga memiliki metabolit sekunder senyawa bioaktif (bioactive subtances) yang memiliki potensi untuk dikembangkan sebagai antimikroba seperti anti bakteri, antijamur, antivirus, dan sebagainya. ${ }^{6,5}$

Penelitian ini dilakukan dengan uji eksperimental dengan tujuan untuk melihat adanya efek antibakteri dari ekstrak rumput laut Gracilaria sp. dalam menghambat pertumbuhan bakteri Staphylococcus aureus. Penelitian ini dilakukan dengan cara membiakkan bakteri Staphylococcus aureus dalam media agar Müller Hinton disertai dengan pembentukan empat buah kertas saring dengan diameter $6 \mathrm{~mm}$. Evaporasi ekstrak dibedakan menjadi dua metode yaitu menggunakan vacuum rotary evaporator dan oven untuk mencari tahu apakah ada efek yang signifikan pada kedua metode dalam menghambat pertumbuhan bakteri Staphylococcus aureus.

Berdasarkan hasil penelitian, zona hambat yang terbentuk dengan 
menggunakan metode evaporasi menggunakan oven dan menggunakan vacuum rotary evaporator tidak memiliki kemampuan untuk menghambat pertumbuhan koloni bakteri Staphylococcus aureus. Menurut penelitian yang dilakukan oleh Bell pada tahun 1984, suatu bahan dikatakan mempunyai aktivitas antibakteri apabila diameter hambatan yang terbentuk lebih besar atau sama dengan $6 \mathrm{~mm}$. Hasil penelitian yang dilakukan menunjukan bahwa zona hambat dari ekstrak Gracilaria sp. yang dievaporasi dengan oven pada masing-masing pengulangan ialah $2,5 \mathrm{~mm}$, $3,5 \mathrm{~mm}, 3 \mathrm{~mm}$. Demikian juga zona hambat yang terbentuk dari ekstrak Gracilaria sp. yang dievaporasi dengan vacuum rotary evaporator pada masingmasing pengulangan ialah $2 \mathrm{~mm}, 2 \mathrm{~mm}$, dan 2,5 mm tidak mempunyai aktivitas antibakteri karena diameter hambatan yang terbentuk kurang dari $6 \mathrm{~mm}^{7}$

Di sekitar cakram kertas saring yang diberi etanol 95\% sebagai kontrol negatif tidak ditemukan terbentuknya zona hambat. Pemilihan pelarut menggunakan etanol 95\% dengan pertimbangan bahwa etanol mudah diperoleh, bereaksi netral, selektif dan tidak mempengaruhi zat yang berkhasiat. Pada masing-masing pengulangan ialah $3,5 \mathrm{~mm}, 5,5 \mathrm{~mm}, 4,5$ mm. Hal tersebut menguatkan fakta bahwa tidak ada efek dari pelarut etanol 95\% dengan terbentuknya zona hambat di sekitar cakram yang diberi ekstrak rumput laut Gracillaria sp.

Dalam penelitian ini tampak bahwa amoxicillin sangat efisien dalam menghambat pertumbuhan bakteri Staphylococcus aureus. Dengan hasil pada masing-masing pengulangan 29,1 mm, 31,5 $\mathrm{mm}, 27,5 \mathrm{~mm}$. Faktor yang mempengaruhi terjadinya hal tersebut yaitu minimal inhibitory concentration (MIC) amoxicillin telah diketahui. Sedangkan untuk kemampuan Gracilaria sp. tidak menghambat pertumbuhan bakteri Staphylococcus aureus.

Parameter untuk mengukur kekuatan senyawa bioaktif yang terkandung dalam ekstrak Gracilaria sp. dapat dilihat dari lebar diameter zona hambat. Semakin lebar diameter zona hambat yang terbentuk maka semakin kuatnya senyawa bioaktif itu menghambat pertumbuhan bakteri. Ekstrak yang menunjukan zona hambat yang kecil bukan berarti sampel tersebut kurang aktif, tetapi kemungkinan tidak terdeteksi pada konsentrasi sampel uji yang digunakan atau kadar hambat umunya belum tercapai. ${ }^{7}$

Hasil penelitian ini berbeda dengan hasil penelitian sebelumnya yang dilakukan oleh Melki, Wike Ayu, Kurniati pada tahun 2011. Penelitiannya dilakukan dengan cara mengekstraksi rumput laut Gracilaria sp. menggunakan pelarut metanol $70 \%$ diujikan pada bakteri Staphylococcus aureus dan Eschrichia Coli. Pada penelitian tersebut menunjukan bahwa ekstrak Gracilaria sp. mengandung senyawa antibakteri yang menghambat pertumbuhan bakteri Staphylococcus aureus dan Eschrichia Coli. Sedangkan pada hasil penelitian ini Gracilaria sp. diekstraksi dengan menggunakan pelarut etanol 95\% diujikan pada bakteri Staphylococcus aureus tidak mengandung senyawa anti bakteri. Hasil penelitian sebelumnya yang dilakukan Melki dengan hasil positif dan penelitian ini dengan hasil negatif memiliki perbedaan dari cara perhitungan. Perhitungan dari penelitian sebelumnya dengan menjumlahkan panjang sisi sebelah kiri sampai sisi sebelah kanan zona hambat serta luas diameter cakram, sedangkan penelitian ini menjumlahkan panjang diameter vertikal dan horizontal dikurangi luas diameter cakram dibagi dua. ${ }^{8}$

Berdasarkan hasil penelitian ini bahwa Gracilaria sp tidak memiliki daya hambat terhadap bakteri Staphylococcus aureus namun, seperti halnya rumput laut pada umumnya Gracilaria sp. memiliki manfaat sebagai media biakan bakteri, bahan makanan, bahan kedokteran gigi seperti alginat dan bahan dasar kosmetik.

\section{SIMPULAN}

Dari hasil penelitian ini dapat disimpulkan, bahwa ekstrak rumput laut Gracilaria sp. tidak memiliki daya hambat 
terhadap bakteri Staphylococcus aureus.

\section{SARAN}

Dari penelitian ini dapat disarankan perlu dikembangkan metode dan teknik penelitian yang lebih canggih untuk dapat menggali informasi tentang kemampuan yang sebenarnya dari rumput laut Gracilaria. sp. sebagai antibakteri. Selain itu, diharapkan untuk melakukan penelitian dengan teknik yang berbeda guna mengetahui daya hambat rumput laut Gracilaria sp. terhadap bakteri Staphylococcus aureus serta berbagai jenis bakteri lainnya.

\section{DAFTAR PUSTAKA}

1. Bakti Husada. Riset kesehatan dasar. Badan penelitian dan pengembangan kesehatan kementerian kesehatan RI. 2013. Depkes. h:x,111.[online] 2013 [cited 2014 november 11]; Available_from:URL:http://www.depkes .go.id/resources/download/general/hasil \%20Riskesdas\%202013.pdf.

2. Bhargavi S, Gopala V, Mukkanti K, Dinesh B, Krishna P. Increasing emergence of antibacterial resistance mainly in uropathogens: southest part of India. Internasional journal of microbiology research. 2010;3(1): p.1-7.

3. Nilai gizi dan manfaat rumput laut bagi kesehatan. Permathic blog. [online] 2013 [cited 2014 November 11]; Available_from:URL:http://permathic.bl ogspot.com/2013/07/nilai-gizi-danmanfaat-rumput-laut-bagi.html.

4. Anggadiredja J A. Zatnika A. Purwoto H. Istini S. Rumput Laut. Pembudidayaan Pengolahan dan Pemasaran Komoditas Perikanan Potensial. Surabaya: p.7-13.

5. Sormin $\mathbf{R}$ B D. Komposisi Kimia dan Potensi Bioaktif Sayur Laut (Porphyra sp). Ambon: Universitas Pattimura Fakultas Perikanan dan Ilmu Kelautan Program Studi Teknologi Hasil Perikanan. p.77.

6. Hutasoit S, Suada I K, Susrama I G K. Uji Aktifitas Antijamur Ekstrak Beberapa Jenis Biota Laut terhadap Aspergillus flavus LINK dan Penicillium sp.LINK. E-JurnalAgroekoteknologi Tropika. 2013: v.2(1). Denpasar. p.27-8.

7. Warbung Y Y dkk. Daya Hambat Ekstrak Spons Laut Callyspongia sp terhadap Pertumbuhan Bakteri Staphylococcus Aureus. Program Studi Kedokteran Universitas Sam Ratulangi. Manado: 2013. p. 2, 6-9.

8. Melki, EP Wike Ayu, Kurniati. Uji Antibakteri Ekstrak Rumput Laut terhadap Bakteri Eschrichia Coli dan Staphylococcus Aureus. Program Studi Ilmu kelautan FMIPA Universitas Sriwijaya. 2011. 